\title{
EARLY HISTORY OF AVIATION IN THE EASTERN PROVINCE
}

\author{
Major General T.G.E. Cockbain SSA, SM \\ Port Alfred
}

\begin{abstract}
Let me firstly state categorically that the Eastern Province is the cradle of aviation in South Africa. Although Admiral John Weston built the first aircraft in South Africa at Brandfort in the Orange Free State in 1907, his machine was taken overseas for its first flight on 10th December 1910. It was not flown here until June, 1911. ${ }^{2}$ When one asks the question, "who made the first ever heavier-thanair flight?", the answer is invariably "the Wright brothers at Kittyhawk, USA in 1903". Who made the first flight of this type in South Africa? A scant six years after the Wright brothers, Albert Kimmerling flew on 28th December, 1909, in a Voisin single-seater biplane at East London. This historic flight took place near the Nahoon racecourse. "The aeroplane answered his every wish, swooping, turning and twisting in a marvellous fashion at about thirty miles per hour" wrote an excited reporter of the great occasion. The flight was repeated on New Year's Day, ending in a minor crash. Thus occurred the first air crash on South African soil. Fortunately the damage was slight and the flying programme soon continued.
\end{abstract}

Early in 1909, the Gala Subcommittee of the East London Town Council issued a notice to the effect that any aeroplane or flying machine demonstration would be welcome at East London during the forthcoming Gala Season. Messrs Howard, Farrar and Robinson then offered to import one of the most modern powerdriven aircraft and an 'expert aviator' from France for the purpose. The 'expert aviator' turned out to be Monsieur Albert Kimmerling, who did not even have a pilot's licence! The machine arrived in East London on 18th December, 1909 with its mechanic, J. Moller and was immediately assembled. ${ }^{3}$ He was replaced in March, 1910 by Horace Barnes of East London. Horace Barnes himself deserves special mention, for he went on to fly the Voisin on the many occasions when Kimmerling was "unwell", having imbibed too freely! Oh! the penalties of being feted as a celebrity. Thus Horace Barnes became the first South African to fly an aeroplane in South Africa. His daughter, Mollye Wilson is with us here today. I am indebted to her for a great deal of information and several newspaper cuttings about her famous father.

Details of this historic aircraft were as follows:

Engine: 7-cylinder Gnome Rotary of 50 h.p. driving a two-bladed aluminium propeller

Weight: $1250 \mathrm{lbs}$ without pilot

Flight History: Logged roughly 80 flights of which some were only very short 'hops'. During these flights, 5 major and $25 \mathrm{mi}-$ nor crashes were suffered.

Configuration: Pusher-type biplane which had two main wheels, a nose-wheel for landing and twin tailwheels for taxying.

Longest Flight: Between 10 and 20 miles at a height of $300-500$ feet.

(The above taken from notes by M.I.Ries, ${ }^{4}$ Kimmeling's Manager)

The greatest chapter of aviation history was written during the Great War of 1914-1918. In this period, many of the makers of aviation history in the following two decades made their debut. The development rate of new aircraft was rapid.

Hans Immelman, brought up in Uitenhage, Eastern province, joined the German Luftwaffe. Regarded as one of their greatest air aces, he was shot down in June, 1916 by another South African, Captain G.R. McCubbin, DSO. To complete the Eastern province involvement, Captain Allister Miller, DSO, of whom more

Notes on Voisin lent by Mrs M.E. Wilson. 
later, flew over a Geman airfield and dropped a wreath on behalf of the Royal Flying Corps in honour of Immelman.

Allister Miller became one of South Africa's pioneers of commercial aviation and the principal agitator for South African aviation development between the two world wars. Much of his flying activity was concentrated in the Eastern province. Born on the 10th September, 1892, at Schombeni, Swaziland, Allister Macintosh Miller received his schooling at St Aidan's College, Grahamstown. He spent a year at Rhodes University before enrolling as an engineering student at City and Guilds College, London University in 1912. He received the OBE and DSO, retiring at the end of the Second World War as a lieutenant colonel. Nevertheless, he is usually remembered as "Major" Miller because it was in this rank that his great reputation was won. He died at "Journey's End" in Port Elizabeth on 15th October, 1957. War hero, recruiting officer for the RFC, barnstorming pilot, pioneer of South African commercial flying, member of Parliament, aviation entrepreneur and great gentleman, Allister Miller wrote a magnificent page in the aviation history of the Eastern province and, indeed, of South Africa. I had the great privilege of serving under him at Queenstown during the Second World War. His first significant contact with this area came during his second recruiting tour. In the course of this tour, he recruited over 2000 candidates to be sent to England for flying training. This tour started from Cape Town on 8th November, 1917 in his B.E.2E biplane "Rio de Janeiro Briton No.2". Flying at an average speed of 70 m.p.h., he reached Port Elizabeth in 5 hours and 22 minutes. Major Miller thus set the first real non-stop distance record in South Africa. ${ }^{5}$ A public holiday was declared and a crowd of 10000 people thronged the fairways of the golf course where the aircraft was to land. This landing turned out to be rather hazardous. As Miller approached the 18th fairway, the crowd surged forward, obliging him to end up in a bunker, damaging the propeller and the undercarriage. After repairs, Miller flew to East London and Queenstown, then onwards to the Orange Free State and Transvaal. Even little Port Alfred was visited in February, 1920 by Major Miller in his Avro 504K. I have this on good authority from one who was a baby at the time and was named after the aircraft - Mr Avro Randall. The landing took place on the old flats area where the Marina is now.
Several noteworthy aviation events occured over the next few years. On 12th April, 1925, Wing Commander C.W.H. Pulford landed at Cape Town with his flight of 5 Fairey-Napier aircraft, having flown from Cairo. These aircraft were equipped with Napier Lion 450-hp 12 cylinder engines giving them top speed of 120 $\mathrm{mph}(193 \mathrm{~km} / \mathrm{h})$. On their return, this formation flew over our farm near Alicedale and as a lad of 7 years old, I saw my first aircraft. Those silver shapes droning slowly across the blue sky kindled a love affair with flying which has never faded. I determined that one day, I too, would tread the boundless halls of blue above!

In those years, some experimental air mail flights were made, including a service between Cape Town, Port Elizabeth, East London and Durban flown by the South African Air Force, using DH 9 aircraft. This venerable World War I aircraft, powered by a de-rated ArmstrongSiddely Puma engine of $230 \mathrm{hp}$., was part of the 42 DH9's provided to South Africa in the Imperial Gift. One of these machines still exists in the South African National Museum of Military History in Johannesburg. A proving flight was made on 23rd February 1925 when two aircraft left Durban bound for Cape Town with relays at East London, Port Elizabeth and Mossel Bay. The personnel involved read like a "Who's Who" of the old South African Air Force - Major H. Meintjies, Major "Happy Jack" Holthouse, Captain C.W. Meredith, Captain H.C. Daniel, Lieutenant L. Tasker, Lieutenant R.F. Caspereuthus, with Lieutenant Colonel Kenneth van der Spuy in administrative control. On the 24th February, the first 5 SAAF aircraft to operate in the Eastern Province landed at Fairview airfield, Port Elizabeth. After the successful test flight on the 23rd February, the first official air mail flights started on Monday, 2nd March, 1925. Mail from the "Windsor Castle" was flown to Durban in 8 hours 15 minutes. The return flight on 5th March took two days, with the mail reaching Cape Town at $1.57 \mathrm{pm}$ on the 6th in ample time to catch the mailship "Armadale Castle", which sailed at 4 pm. ${ }^{6}$ Having proved the reliability of the air mail service after flying 91250 miles without serious mishap, the experiment ended on 27th June, 1925. ${ }^{7}$

Another great exploit was that of Captain Stan Halse who, in a.Gipsy Moth, flew his wife from London to Queenstown in 1929. However this event has passed almost unnoticed while Sir

\footnotetext{
H. Klein : Winged Courier (Cape Town, 1955), p.27.

H. Klein: Winged Courier, p.55-56.

Ron Belling : Military Aviation in South Africa (Cape Town, 1989), p. 12
} 
Alan Cobham, van Lear Black, Lady Mary Bailey, Lady Heath, Amy Mollison, Lieutenant Pat Murdoch and many other record-seekers on the London - Cape Town route were writing aviation history elsewhere. Judging by the number of ladies' names who flew that route, it seems that womens' lib in the 1920s had no need to burn their bras! Their publicity was otherwise assured!

After his continual efforts to persuade the government of the viability of a commercial air service, Major Miller obtained a subsidy to start a coast-wise airmail service. A feeder service to Johannesburg was also authorised. On the 29th July, 1929, Union Airways (Pty) Ltd., was registered with a capital of 5000 pounds sterling. Port Elizabeth was selected as the headquarters of the company. Offices were established at the old Fairview Aerodrome. A fleet of five DH Gipsy Moth aircraft was specially imported to fly mail and for charter flights. At 7.42 a.m. on Monday 26th August, 1929, Major Miller took off from the Maitland Aerodrome, Cape Town with five bags of mail from RMS "Saxon", bound for Port Elizabeth. ${ }^{8}$ The flight took four-and-a-half hours. $\mathrm{He}$ immediately handed over the mails to a waiting relay aircraft for onward transmission to Durban and Johannesburg. Return flights left Durban and Germiston on 29th August for Port Elizabeth. From there, Major Miller again flew the Cape Town leg, arriving at 1.40 p.m. in plenty of time for the departure of the "Carnarvon Castle" at 4 p.m. In the first six months, Union Airways flew 130000 miles, over 1000 flying hours, carried 104 passengers and 6161 pounds of mail without a single mishap or penalty for late delivery. Unfortunately by the end of 1931, various misfortunes and crashes had dealt severe financial blows to the fledgling company. On 22nd January, Union Airways flew their brand new Fokker Super Universal aircraft at Port Elizabeth for the first time. Engined with a Pratt \& Whitney Wasp of $420 \mathrm{hp}$ and affectionately known as the "Red and Yellow Monster", this 6-seater aircraft was to usher in a new standard of luxury air travel. Rejoicing was to be short-lived as Major Miller, flying this new aircraft, left East London in bad weather on 31st December, 1931 and crashed at Kayser's Beach, about 25 miles south-west of the town. Although the pilot and the two passengers were uninjured, the aircraft was a write-off. Union Airways was forced to re-organise to remain solvent. They took the German Junkers Company into a loose partnership and the headquarters of the first commercial airline in South Africa left the Eastern Province for Durban. On 1st February, 1934, the then Union Government acquired the assets and liabilities of Union Airways. South African Airways was born.

On Sunday, 12th July 1931, Captain Stan Halse, flying a Puss Moth with Mr. I. Frankel, Johannesburg lawyer, had a frightening "Siberian Adventure". Overtaken by a snowstorm over the Stormsberg in July, 1931, they forcedlanded. Thrown out of the aircraft, Halse injured his leg. Uninjured, Frankel set out to find help. After walking through blinding snow for about 2 hours, he found the farm "Lemoenkloof". Halse was rescued about five hours after the crash and taken to the farm where they remained snow-bound from Sunday to Wednesday afternoon. They were then taken to nearby Dordrecht. ${ }^{9}$

Another drama of that period took place at East London's Woodbrook aerodrome. An aircraft destined for the Aliwal North Roman Catholic Mission was assembled during the morning of 6 th June, 1934. Apparently without adequate test flight or inspection, the pilot, one Marti, took off the same afternoon for Aliwal North. The aircraft crashed immediately after take-off. The pilot and the two passengers were killed. ${ }^{10}$

The involvement of Port Alfred in the early days of aviation included the making of a landing field in 1931 by Bob Finn. Finn removed some antheaps and a few thorn bushes on the site of the present airfield. This was to allow Major Miller to carry out landing and take-off tests for the certification of his 6-seater Fokker for use by Union Airways. Two local men, Gerard Stocks and Leo Strauch provided fuel and also smoke generators as wind direction indicators. This site became an emergency landing ground for South African Airways during the 1930s and was used during take-off tests for their Junkers Ju.52s in 1936. Later it was developed as 43 Air School for wartime training, using Ansons, Oxfords and Fairey Battles.

Interest in flying as a sport was growing apace. Flying clubs sprang up at East London, Port Elizabeth and, later at Grahamstown. Private owners of aircraft started to expand their flying horizons and flying became a popular sport. The Port Elizabeth Light Aeroplane Club was formed on 8th January 1928 and operated until

H. Klein : Winged Courier, p.72.

Grocott's Daily Mail (Grahamstown), 17 Jul 1931.

Grocott's Daily Mail. 7 Jun 1934.

Grocott's Daily Mail. 31 Jan 1933. 
October, 1931. This club was re-established in June, 1936 as the Port Elizabeth Aero Club. The visit of Sir Alan Cobham's Flying Circus to the area early in 1933 further stimulated interest in aviation. I well remember the Flying Circus visiting Grahamstown on Monday, 6th February, 1933. ${ }^{11}$ Places of business closed at 3 p.m. to allow their staff to see the show. A three-engined (Bristol "Jupiter" 420 hp (315 $\mathrm{Kw}$ )) Imperial Airways "Hercules" airliner gave flips. Now on its second visit (the first being on 26th May, 1932 to Port Elizabeth), this 14-passenger aircraft was the largest to have visited the Eastern province at this time. The Ceivra Autogyro (a forerunner of today's helicopters) which also flew in Cobham's circus was making the first appearance in South Africa of a rotarywinged aircraft. As it had no power driving the rotor, the pilot had to taxi at high speed until the rotor spun fast enough; a rather time-consuming procedure. This show was also notable for the test of a locally designed and manufactured parachute. This project was carried out by a schoolmaster from St Andrews, Mr Milner, and a Miss Alison Pierson. Unfortunately, the cords tore away on opening and the 50 pound 'dummy' plunged to earth!

Mr Reg Westaway, a Grahamstown garage owner, was a great aviation enthusiast. He bought a DH Puss Moth which was hangared in a small shed against the Golf Course fence of the airfield. His first pilot was the Victor Smith of London - Cape Town flight fame. After the crash of this aircraft, Westaway bought a Hornet Moth, a very luxurious machine with wings which folded back for storage. His next pilot was Pidsley. Sadly, he was killed in this aircraft in a crash in the Somerset East mountains in 1937.

Grahamstown Flying Club was formed in 1937. The committee was Advocate (later Justice) van der Riet as chairman, Vicent Groccott as treasurer and Colonel F.R. Bartlett as honorary secretary. This club flourished until World War II interrupted civilian flying in 1939. (It was resurrected in 1966.) At this stage, the Government started the Pupil Pilot Training Scheme for pilots at the various flying clubs throughout the country. George Haller had founded Haller Aviation in Port Elizabeth in 1937 and soon extended his flying school activities to East London and Grahamstown. This company provided the necessary aircraft and support for the Grahamstown operation. The instructors included Helen de Waal (neé Harrison), Jack Dalrymple and John Meiring. The two latter instructors gave their lives during World War II while serving in the South African Air Force
(SAAF). Helen de Waal possessed a suprisingly vivid and sometimes quite appropriate vocabulary which was a source of envy among her pupils! She was my first flying instructor 55 years ago. In those days, the hangar was situated on the western boundary of the airfield which was much smaller than it is now. Care of the Ryan ST and Aeronca aircraft in use was in the capable hands of "Mac" McGee, later a senior engineer officer on Sunderland flying boats of the SAAF.

With the outbreak of World War II in September, 1939, the aviation scene in the Eastern Cape changed radically. Flying schools and private flying was stopped by the end of March, 1940. In search of suitable training areas away from the theatre of war, the Royal Air Force (RAF) started the Empire Training Scheme. Survey parties visited the main Commonwealth countries, including South Africa during early 1941. Airfields in the coastal area were selected for nine navigation, bomb-aiming and air gunnery training schools. Of these airfields, five lay in the Eastern province, that is at Port Elizabeth, Grahamstown, Port Alfred, Queenstown and East London. Established in Port Elizabeth under the command of Air Commodore Croake, RAF, 25 Group Headquarters controlled these units. The construction of these schools brought much employment and prosperity to the chosen centres. Hangars were erected, accommodation and messes were built. The necessary technical facilities were provided. Airfields were enlarged and improved to meet the influx of men and aircraft towards the end of 1941. Port Alfred was allotted No 43 Air School. Work on this airfield began in September 1941 under the engineering supervision of Captain Brian Loffell, now a resident of Port Alfred. Building of the facilities for the 1800 men and women was still incomplete upon the arrival of the first contingent of Royal Air Force personnel on 5th December, 1941. Stories of their early misadventures in the tented camp deserve a separate talk! In spite of a severe water shortage, training commenced at the beginning of 1942 . The cost was stated to have been 550000 pounds. The work also involved the construction of two satellite facilities at Rufane's River (Green Valley bombing range) and Grant's Valley (for aerial gunnery).

Numerous anecdotes have survived from this colourful period. Picture a night in the 43 Air School Officers' Mess. The year is 1943 and it is the night of a dance and party. Two newly arrived pilots were chatting on the south side of the lounge. Joined by their Officer Command- 
ing, Colonel Robbins, Pixie Frewen asked "Excuse me, Sir, but who is the old hag by the fireplace?" Frostly reply from Colonel, "That is my wife". Exit Frewen through the open window. The wartime 43 Air School closed down in 1945. In 1989, Mr. Jim Davis took over part of the then derelict portion of the old wartime school and established a modern civil flying school for pilot training. Roofless buildings were re-roofed with immacualte thatch and the interiors renovated. Lecture rooms and an airfield control tower were built. The upgraded facilities provided for 50 students. Reviving the old wartime name, Davis called his new training school "43 Air School". It has become the largest private flying school in the Republic and a worthy sucessor of its wartime namesake.

Flying training schools of those years also served as a back-up for the coastal operational activities. Most of these schools had reserve squadrons, identified by a "1" placed before the school designator, that is the operational portion of No.44 Air School (Grahamstown) was named No.144 Reserve Squadron. These units took part in anti-submarine and limited convoy escort duties, armed with depth charges. This was in addition to their training function. With the advent of peace, these training schools were closed down in 1945. The RAF component returned to the United Kingdom and SA Air Force personnel were either demobilised of absorbed into the peace-time air force. Most of the airfields thus released became civilian fields serving their nearest towns. No.43 Air School was retained until 1952 as an air force base with the intention of establishing a maritime reconnaissance station. This did not materialise, so the buildings were left to deteriorate and the hangars moved to Pretoria, becoming part of the present 4 Air Depot. The airfield itself was used as an unattended landing ground for Port Alfred until the advent of Mr. Jim Davis and his flying school. At 44 Air School, buildings and hangars became an Army stores depot and an infantry training centre. The airfield became the Grahamstown civil field and the base of their flying club, revived in 1966, and of Albany Flying Services.

Post-World War II history became more mun- dane; the days of famous flyers and their records were largely in the past. Certain aircraft visits do however, deserve mention. On 8th April, 1945 "Aries", an Avro Lancaster bomber from the Empire Navigation School at Shawbury in the United Kingdom paid a visit to Port Elizabeth. After orbiting the city, it landed at St Albans. Lancasters were the most famous of the RAF heavy bombers of World War II. These remarkable aircraft took part in renowned exploits such as the "Dambusters" raid on the Mohne and Eder dams in Germany. They also bore the brunt of the night bombardment of Europe. Although these aircraft could normally carry a warload of $14000 \mathrm{lbs}$, they were modified to carry the 10-ton "Grand Slam" bomb and other specialised armament. Another aircraft of the same family, the Avro York No. 4999 anded at St Albans in 1947. This was the /IP aircraft of the Prime Minister's Flight used by Field Marshal J.C. Smuts on nost of his overseas trips after mid-1944. It carried many notables, including the Greek Royal family and high-ranking diplomats. I had the privilege of being a member of the flying crew of this aircraft, flying over 1150 hours in its spacious cockpit. The York was a derivative of the Lancaster, using its wing, undercarriage, tailplane and engines. An additional central fin was added to counteract the increased keel area offered by the deep square fuselage cross-section. Winston Churchill used the third York off the Avro production line, (RAF No. MW 103). MW 107, renumbered 4999 by the SA Air Force, became the South African Prime Minister's personal aircraft.

I would like to thank Mrs. Mollye Wilson for her reminiscences of her father Horace Barnes, and for the use of her numerous newspaper cuttings about him and the Voisin aircraft. My thanks also go to the Cory Library of Rhodes University for research facilities and to Mr. Glen Harvey for his useful material. Mr. Ron Belling has been a great help in obtaining information, for which I thank him. I am indebted to many others for information and anecdotes. This little collection of information will, I hope, be of use to future researchers into the annals of aviation history. 